\title{
Using Pyroxasulfone for Downy Brome (Bromus tectorum L.) Control in Winter Wheat
}

\author{
Vipan Kumar ${ }^{*}$, Prashant Jha1, Amit J. Jhala² \\ ${ }^{1}$ Department of Research Centers, Southern Agricultural Research Center, Montana State University, Bozeman, \\ MT, USA \\ ${ }^{2}$ Department of Agronomy and Horticulture, University of Nebraska-Lincoln, Lincoln, NE, USA \\ Email: *vipan.kumar@montana.edu
}

How to cite this paper: Kumar, V., Jha, P. and Jhala, A.J. (2017) Using Pyroxasulfone for Downy Brome (Bromus tectorum L.) Control in Winter Wheat. American Journal of Plant Sciences, 8, 2367-2378.

https://doi.org/10.4236/ajps.2017.810159

Received: July 25, 2017

Accepted: September 3, 2017

Published: September 6, 2017

Copyright (c) 2017 by authors and Scientific Research Publishing Inc. This work is licensed under the Creative Commons Attribution International License (CC BY 4.0).

http://creativecommons.org/licenses/by/4.0/

\begin{abstract}
Downy brome is one of the most troublesome weeds in no-till wheat production systems of the US Great Plains. Pyroxasulfone is a relatively new, soilapplied residual herbicide (root/shoot growth inhibitor) labeled for use in wheat. Multiple field experiments were conducted near Huntley, MT from 2012 through 2016 to determine the efficacy of pyroxasulfone to control downy brome in imidazolinone (IMI)-tolerant (Clearfield ${ }^{\mathrm{mw}}$ ) winter wheat. Pyroxasulfone did not cause any injury to wheat in any of the three studies. Downy brome injury with pyroxasulfone preemergence (PRE) only program did not differ between 89 or $178 \mathrm{~g}$.ai (active ingredient). $\mathrm{ha}^{-1}$ rates, and averaged $82 \%$ and $84 \%$ in 2 separate studies. In a preplant (PP) burndown program, the addition of pyroxasulfone (178 g.ai $\cdot \mathrm{ha}^{-1}$ ) to glyphosate improved downy brome end-season injury from $15 \%$ to $74 \%$. In a separate study, the end-season injury with pyroxasulfone was greater when applied PRE (84\%) compared to the delayed PRE (DPRE) timing (74\%). In addition, the water dispersible granule (WDG) formulation of pyroxasulfone performed slightly better than the suspension concentrate (SC) formulation for downy brome injury. Pyroxasulfone applied PRE in the fall at a rate of $89 \mathrm{~g} \cdot \mathrm{ai} \cdot \mathrm{ha}^{-1}$ followed by $(\mathrm{fb})$ imazamox (44 g.ai.ha ${ }^{-1}$ rate) applied postemergence (POST) in the spring effectively controlled downy brome (99\% end-season injury). Furthermore, the injury was consistent with the standard program comprising of propoxycarbazone (29 g.ai.ha $\left.{ }^{-1}\right)$ PRE fb imazamox POST in IMI-tolerant winter wheat. In conclusion, pyroxasulfone applied PRE in the fall can be effectively utilized in conjunction with a standard acetolactate synthase (ALS)-inhibitor-based POST herbicide program for a season-long downy brome management in winter wheat.
\end{abstract}

\section{Keywords}

Downy Brome, Pyroxasulfone, Soil-Applied Herbicide, Herbicide Rate, 
Application Timing, Formulation, Wheat

\section{Introduction}

Wheat (Triticum aestivum L.) is an important cereal grain crop well suited for dryland cropping systems of the northwestern United States, including Montana. In 2015, Montana ranked third among the wheat producing states, accounting for $9 \%$ of the total US wheat production [1]. About $75 \%$ of the total wheat grown in the United States is winter wheat [2], which is primarily grown in rotation with chemical fallow, pulse crops (dry pea, chickpea, or lentil), or canola in this region. Weed management is a major obstacle in successful winter wheat production [3], and a season-long weed infestation can cause severe reductions in yield and grain quality of winter wheat [4] [5].

Downy brome (commonly known as cheatgrass) is an invasive, self-pollinated, winter annual grass weed, widespread in rangeland and winter wheat production areas of this region [6]. It is a native of Mediterranean region of Europe, and was first identified in the United States in 1861 in New York and Pennsylvania [7]. Currently, downy brome infests 23 million hectares in 17 states in the northwestern United States [8]. The increased downy brome abundance in the semi-arid wheat production systems is attributed to the adoption of no-till practice, mainly for soil moisture conservation and soil erosion prevention, and limited selective herbicides for downy brome management [6]. Downy brome seeds are short-lived (1 to 2 years), best germinating at $20^{\circ} \mathrm{C}$, and seedlings emerge from shallow soil depths (1 to $5 \mathrm{~cm}$ ) [9] [10]. Fall-emerging downy brome seedlings overwinter in a semi-dormant state and resume growth in the spring after winter vernalization. Those plants attain physiological maturity by mid-June in this region [11]. Downy brome is a prolific seed producer (up to 2.6 billion seeds ha ${ }^{-1}$ ) [12].

Downy brome interference in winter wheat has been studied extensively, and moderate to severe grain yield reductions have been reported [9] [13] [14] [15]. Downy brome at densities of 24,40 , and 65 plants. $\mathrm{m}^{-2}$ reduced winter wheat yields by $10 \%, 15 \%$, and $20 \%$, respectively [15]. In a study conducted in Washington, a moderate infestation of downy brome at a density of 54 plants $\cdot \mathrm{m}^{-2}$ reduced winter wheat yield by $28 \%$ [14]. High levels of downy brome infestation $\left(>500\right.$ plants $\left.\cdot \mathrm{m}^{-2}\right)$ can cause near-total $(>92 \%)$ yield loss in winter wheat [14].

The timing of downy brome emergence has a greater influence on wheat yield reductions than the plant density [8] [15]. The early-emerging cohorts of downy brome (that emerged between planting and 1 to 2 weeks after winter wheat emergence) were found to be more competitive than the late-emerging cohorts (that emerged after 3 weeks of winter wheat emergence) [13] [15]. For instance, downy brome at densities of 200 to 400 plants $\cdot \mathrm{m}^{-2}$ that emerged in the fall with winter wheat, reduced winter wheat yields up to $68 \%$ [13]. Up to $40 \%$ winter wheat yield reductions were observed when fall-emerging downy brome at 132 
plants $\cdot \mathrm{m}^{-2}$ were not controlled by early spring; however, the yield loss was only $6 \%$ when those plants were removed by March [9].

Growers rely on selective herbicides for downy brome management in wheat. A majority of these herbicides belong to five different ALS-inhibiting herbicide families, including sulfonylureas (SU), imidazolinones (IMI), triazolopyrimidines (TP), pyrimidinylthiobenzoates (PTB), and sulfonylamino-carbonyl-triazolinones (SCT). However, the intensive use of these ALS-inhibiting herbicides has resulted in the evolution of ALS-resistant downy brome biotypes [16]. For instance, a downy brome biotype with cross-resistance to imazamox (IMI), propoxycarbazone-sodium (SCT), and pyroxsulam (TP) has recently been reported from an IMI-tolerant winter wheat field in Montana [17]. Similarly, downy brome biotypes with cross-resistance to primisulfuron, sulfosulfuron, imazamox, and propoxycarbazone have been documented from Kentucky bluegrass fields in Oregon [18] [19], suggesting the need to revisit effective weed control programs and investigate alternative herbicide chemistries for downy brome management.

Pyroxasulfone is a relatively new soil-applied premergence (PRE) herbicide that acts as a root/shoot growth inhibitor in germinating seedlings of both grassy and broadleaf weeds [20]. It is registered in several crops including wheat, corn (Zea mays L.), soybean [Glycine max (L.) Merr.], sunflower (Helianthus annuus L.), and dry bean [21] [22] [23]. Pyroxasulfone applied PRE in wheat controls grass weeds such as, Italian ryegrass (Lolium perenne ssp. multiflorum) and rigid ryegrass (Loliumrigidum) [21] [24] [25]. However, there is very little information available on the effectiveness of pyroxasulfone for downy brome management in wheat. The objectives of this research were: 1) to evaluate pyroxasulfone applied PRE standalone or followed by (fb) a standard POST herbicide program; 2) compare the effectiveness of pyroxasulfone with other standard preplant (PP) glyphosate-based herbicide programs (standalone) or $\mathrm{fb}$ a POST herbicide program; and 3) compare the efficacy of pyroxasulfone formulation, rate and application timing for crop safety and season-long downy brome injury and grain yields in IMI-tolerant $\left(\right.$ Clearfield $^{\circledR}$ ) winter wheat.

\section{Materials and Methods}

Three separate field experiments were conducted at the Montana State University Southern Agricultural Research Center (MSU-SARC) near Huntley, MT, during 2012 through 2016 to achieve the aforementioned objectives (1,2, and 3). Soil was a Fort Collins clay loam (fine loamy, mixed, superactive, mesic Aridic Haplustalfs) with a $\mathrm{pH}$ of $7.8 \%$ and $2.1 \%$ organic matter. Monthly mean air temperature $\left({ }^{\circ} \mathrm{C}\right)$ and total precipitation $(\mathrm{mm})$ were recorded at a weather station located approximately $1 \mathrm{~km}$ from the test site. Plots were $3 \mathrm{~m}$ wide by $9 \mathrm{~m}$ long. An IMI-tolerant winter wheat cultivar "Clearstone CL 2" was seeded 2.5 $\mathrm{cm}$ deep in $19-\mathrm{cm}$ rows at a rate of $67 \mathrm{~kg} \cdot \mathrm{ha}^{-1}$ using a no-till drill in the first fortnight of October. Plots were fertilized with N-P-K using a gravity-fed broadcast spreader according to the MSU fertilizer guidelines for winter wheat production [26]. The test site for each experiment had a natural uniform infestation of 
downy brome at densities of 60 to 65 plants. $\mathrm{m}^{-2}$. All herbicide treatments were applied with a $\mathrm{CO}_{2}$-pressurized hand-held sprayer equipped with four flat-fan spray nozzles (TeeJetTP8001, TeeJet Technologies, Wheaton, IL 60189) calibrated to deliver $94 \mathrm{~L} \cdot \mathrm{ha}^{-1}$ at $276 \mathrm{kPa}$. Herbicides used in the three experiments are presented in Table 1 . The herbicide application rates were selected based on the labeled rates in IMI-tolerant winter wheat. In all experiments, a nontreated check was included for comparison. The winter wheat crop was harvested using a small-plot combine (Wintersteiger $\mathrm{Ag}$ ) and wheat grain samples were cleaned, and yields were adjusted to $13 \%$ moisture.

\subsection{Pyroxasulfone Preemergence}

Field experiments were conducted in 2012/2013 and 2013/2014 winter wheat growing seasons, and were set up in a randomized complete block design with four replications. The study included three fall-applied preemergence (PRE) standalone treatments, two spring-applied postemergence (POST) standalone treatments, and two PRE followed by ( $\mathrm{fb}$ ) POST treatments. PRE standalone treatments included pyroxasulfone at either 89 or $178 \mathrm{~g} \cdot \mathrm{ai} \cdot \mathrm{ha}^{-1}$ in comparison to propoxycarbazone at $29 \mathrm{~g} \cdot \mathrm{ai} \cdot \mathrm{ha}^{-1}$ (local standard), and were applied immediately after winter wheat planting on October 12 in 2012 and October 7 in 2013. POST treatments included imazamox at $44 \mathrm{~g} \cdot a \mathrm{i} \cdot \mathrm{ha}^{-1}$ or pyroxsulam at $18 \mathrm{~g} \cdot \mathrm{ai} \cdot \mathrm{ha}^{-1}$, and were applied on May 10 in 2013 and May 14 in 2014 when winter wheat and downy brome had broken their winter dormancy and resumed growth (approximately 4 - to 5 -tiller stage of winter wheat). Injury data on crop and downy brome were visually assessed on a scale of 0 to $100 \%$, with 0 representing no injury and 100 representing complete plant death at 2, 5, and 8 weeks after the POST (WAPOST) herbicide application.

Table 1. List of tested herbicides along with adjuvants.

\begin{tabular}{|c|c|c|c|c|}
\hline Active ingredients & Trade name & Manufacturer & Adjuvant $^{\mathrm{a}}$ & $\begin{array}{l}\text { Adjuvant } \\
\text { rate } \% \mathrm{v} / \mathrm{v}\end{array}$ \\
\hline Pyroxasulfone & Zidua $^{\oplus}$ & $\begin{array}{l}\text { BASF Corporation, Research } \\
\text { Triangle Park, NC } 27709\end{array}$ & & \\
\hline Propoxycarbazone & Olympus $^{\oplus} 70$ & $\begin{array}{c}\text { Bayer CropScience, Research } \\
\text { Triangle Park, NC } 27709\end{array}$ & & \\
\hline Saflufenacil & Sharpen $^{\circledast}$ & $\begin{array}{l}\text { BASF Corporation, Research } \\
\text { Triangle Park, NC } 27709\end{array}$ & $\mathrm{MSO}+\mathrm{AMS}$ & $1+20 \mathrm{~g} / \mathrm{L}$ \\
\hline Imazamox & Beyond $^{\oplus}$ & $\begin{array}{l}\text { BASF Corporation, Research } \\
\text { Triangle Park, NC } 27709\end{array}$ & $\mathrm{MSO}+\mathrm{UAN}$ & $1+9.2 \mathrm{~L} / \mathrm{ha}$ \\
\hline Pyroxsulam & PowerFlex ${ }^{\oplus} \mathrm{HL}$ & $\begin{array}{l}\text { Dow AgroScience LLC, } \\
\text { Indianapolis, IN } 46268\end{array}$ & $\mathrm{NIS}+\mathrm{UAN}$ & $0.5+4.6 \mathrm{~L} / \mathrm{ha}$ \\
\hline Glyphosate & $\begin{array}{l}\text { Roundup } \\
\text { PowerMax }\end{array}$ & $\begin{array}{l}\text { Monsanto Company, Saint } \\
\text { Louis, MO } 63167\end{array}$ & NIS + AMS & $0.25+20 \mathrm{~g} / \mathrm{L}$ \\
\hline
\end{tabular}

MSO, methylated seed oil, MSO concentrate, Loveland Products; AMS, ammonium sulfate, Thrust, Loveland Products; UAN, urea ammonium nitrate, Nortrace, Loveland Products; NIS, nonionic surfactant. 


\subsection{Pyroxasulfone Preplant}

Ten preplant (PP) standalone or PP followed by (fb) standard POST herbicide treatments were evaluated for injury on crop and downy brome during the 2013/2014 and 2014/2015 winter wheat growing seasons. Treatments were arranged in a randomized complete block design, with four replications. Treatments included glyphosate applied preplant (PP) at $870 \mathrm{~g} \cdot \mathrm{ai} \cdot \mathrm{ha}^{-1}$ alone or in combination with pyroxasulfone at 89 or $178 \mathrm{~g} \cdot \mathrm{ai} \cdot \mathrm{ha}^{-1}$ or propoxycarbazone at $29 \mathrm{~g} \cdot \mathrm{ai} \cdot \mathrm{ha}^{-1}$ (local standard), in combination with pyroxasulfone at $89 \mathrm{~g} \cdot \mathrm{ai} \cdot \mathrm{ha}^{-1}$ plus saflufenacil at $25 \mathrm{~g} \cdot \mathrm{ai} \cdot \mathrm{ha}^{-1}$; and glyphosate ( $\left.870 \mathrm{~g} \cdot \mathrm{ai} \cdot \mathrm{ha}^{-1}\right) \mathrm{PP} \mathrm{fb}$ imazamox $\left(44 \mathrm{~g}\right.$ aiha $\left.^{-1}\right)$ POST or pyroxsulam (18 gai $\cdot \mathrm{ha}^{-1}$ ) POST. The PP treatments were applied a day before winter wheat planting on October 7 in 2013 and October 10 in 2014, while POST treatments were applied on May 5 in 2014 and May 10 in

2015. Treatments were visually assessed for injury on crop and downy brome at 21 weeks after the PP (WAPP) herbicide application, and 4 and 8 weeks after the POST (WAPOST) herbicide application, using the rating scale as previously described.

\subsection{Pyroxasulfone Rate, Application Timing and Formulation}

Field experiments were conducted in 2014/2015 and 2015/2016, and were set up in a randomized complete block design with a factorial arrangement of treatments, and four replications. Factors included pyroxasulfone formulation, rate, and application timing. Pyroxasulfone formulations tested were water-dispersible granule (WDG) and suspension concentrate (SC). Pyroxasulfone rates included 89 or $178 \mathrm{~g} \cdot$ ai $\cdot \mathrm{ha}^{-1}$. The application timings tested were PRE (immediately after winter wheat planting) and delayed PRE (DPRE; when $80 \%$ of germinated wheat seeds had a shoot at least $1.2 \mathrm{~cm}$ long until wheat spiking). Data on crop and downy brome injury were visually assessed at 24 and 32 weeks after the PRE (WAPRE) application using the rating scale as previously described.

\subsection{Statistical Analyses}

All data were subjected to ANOVA using PROC MIXED in SAS 9.3 (SAS Institute, Inc., SAS Campus Dr., Cary, NC 27513) to test the significance of fixed effects, i.e., year, treatment (herbicide treatment in experiment 1 and 2 and herbicide rate, formulation, or timing in experiment 3 ), and their interactions. Replication and interactions involving replication were random effects in the model. Downy brome percent injury data from the nontreated check plots were excluded from the analysis, while the wheat yield data from the nontreated check plots were included for comparison. Residual analyses were performed using PROC UNIVARIATE and the homogeneity of variance assumption was tested. All data met ANOVA requirements. Treatment means were separated using Fisher's protected LSD at $\mathrm{P} \leq 0.05$.

\section{Results and Discussion}

The 2015/2016 growing season was wetter and warmer compared to 2012/2013 
and 2014/2015 growing seasons (Table 2). However, the interaction of treatment by year was not significant on downy brome injury or winter wheat grain yield in any of the three experiments; hence, data were pooled over the two years.

\subsection{Pyroxasulfone Preemergence}

No winter wheat injury was observed with any of the PRE standalone, POST standalone, or PRE fb POST herbicide program. Among all treatments, pyroxasulfone $\left(89 \mathrm{~g} \cdot \mathrm{ha}^{-1}\right)$ or propoxycarbazone $\left(29 \mathrm{~g} \cdot \mathrm{ai} \cdot \mathrm{ha} \mathrm{H}^{-1}\right)$ PRE followed by imazamox (44 g.ai $\cdot \mathrm{ha}^{-1}$ ) POST were the most effective treatments ( $>97 \%$ injury) for managing downy brome in IMI-tolerant wheat at 2, 5, and 8 WAPOST (Table 3). Downy brome injury with pyroxasulfone (89 or $178 \mathrm{~g} \cdot \mathrm{ai} \cdot \mathrm{ha}^{-1}$ ) PRE alone was greater than propoxycarbazone PRE alone, but comparable to imazamox (44 $\mathrm{g} \cdot \mathrm{ha}^{-1}$ ) POST standalone treatment across all evaluation dates, and averaged $81 \%$ at 8 WAPOST. Although there is no published information on pyroxasulfone efficacy on downy brome, up to $94 \%$ control of Italian ryegrass has been reported with a PRE application of pyroxasulfone $\left(150 \mathrm{~g} \cdot \mathrm{ai} \cdot \mathrm{ha}^{-1}\right)$ in winter wheat [21]. Similarly, pyroxasulfone at rates $\geq 150 \mathrm{~g} \cdot \mathrm{ha}^{-1}$ had up to $90 \%$ control of rigid ryegrass (Loliumrigidum Gaud.) in wheat [27]. Consistent with our results, up to 64\% injury of downy brome has been reported with a fall application of propoxycarbazone PRE at a similar rate in winter wheat, in a study conducted in North Dakota, USA [28]. With imazamox POST, applied even at a lower rate of 35 $\mathrm{g} \cdot \mathrm{ai} \cdot \mathrm{ha}^{-1}$, up to $82 \%$ injury of downy brome has been documented in spring

Table 2. Monthly mean air temperature $\left({ }^{\circ} \mathrm{C}\right)$ and total precipitation for the winter wheat growing periods in 2012-2016 at the MSU Southern Agricultural Research Center near Huntley, MT. The months of October-July represent the critical winter wheat growing season in southcentral Montana.

\begin{tabular}{|c|c|c|c|c|c|c|c|c|}
\hline & \multicolumn{2}{|c|}{$2012-2013$} & \multicolumn{2}{|c|}{ 2013-2014 } & \multicolumn{2}{|c|}{ 2014-2015 } & \multicolumn{2}{|c|}{ 2015-2016 } \\
\hline & $\begin{array}{c}\text { Temperature } \\
\left({ }^{\circ} \mathrm{C}\right)\end{array}$ & $\begin{array}{l}\text { Precipitation } \\
\quad(\mathrm{mm})\end{array}$ & $\begin{array}{c}\text { Temperature } \\
\left({ }^{\circ} \mathrm{C}\right)\end{array}$ & $\begin{array}{l}\text { Precipitation } \\
\quad(\mathrm{mm})\end{array}$ & $\begin{array}{c}\text { Temperature } \\
\left({ }^{\circ} \mathrm{C}\right)\end{array}$ & $\begin{array}{l}\text { Precipitation } \\
\quad(\mathrm{mm})\end{array}$ & $\begin{array}{c}\text { Temperature } \\
\left({ }^{\circ} \mathrm{C}\right)\end{array}$ & $\begin{array}{l}\text { Precipitation } \\
\quad(\mathrm{mm})\end{array}$ \\
\hline Oct. & 7.1 & 29.9 & 6.6 & 63.8 & 10.1 & 6.4 & 10.9 & 57.4 \\
\hline Nov. & 2.3 & 11.1 & 0.9 & 5.1 & -1.5 & 12.5 & 1.3 & 14.3 \\
\hline Dec. & -3.6 & 2 & -6.6 & 23.7 & -2.3 & 8.9 & -3.3 & 8.4 \\
\hline Jan. & -3.2 & 5.4 & -1.5 & 3.6 & -1.1 & 5.1 & -2.9 & 7.4 \\
\hline Feb. & 0.4 & 4.8 & -7.9 & 7.4 & -0.2 & 51.9 & 4.2 & 4.6 \\
\hline Mar. & 2.5 & 5.9 & 0.4 & 40.7 & 6.8 & 3.6 & 5.4 & 43.7 \\
\hline Apr. & 5.7 & 29.8 & 8.3 & 29.8 & 8.9 & 29.0 & 9.7 & 45.3 \\
\hline May & 14.3 & 154.2 & 13.7 & 62.8 & 12.6 & 79.1 & 13.4 & 75.0 \\
\hline Jun. & 17.6 & 34.1 & 16.7 & 70.7 & 20.8 & 50.9 & 21.0 & 99.1 \\
\hline Jul. & 22.9 & 15.5 & 22.8 & 11.2 & 22.2 & 26.4 & 22.7 & 12.0 \\
\hline Total & & 249.7 & & 318.8 & & 273.7 & & 367.2 \\
\hline
\end{tabular}


Table 3. Comparison of pyroxasulfone preemergence with standard herbicide treatments for downy brome injury and grain yield in imidazolinone-tolerant (IMI-tolerant) winter wheat near Huntley, MT in 2012 and $2013^{\mathrm{a}, \mathrm{b}}$.

\begin{tabular}{|c|c|c|c|c|c|c|c|c|c|c|}
\hline \multicolumn{11}{|c|}{ Downy brome injury,d } \\
\hline \multirow[t]{2}{*}{ Herbicide(s) } & \multirow{2}{*}{$\begin{array}{c}\text { Rate } \\
\left(\mathrm{g} \cdot \mathrm{ai} \cdot \mathrm{ha}^{-1}\right)\end{array}$} & \multirow[t]{2}{*}{ Timing } & \multicolumn{2}{|c|}{2 WAPOST } & \multicolumn{2}{|c|}{5 WAPOST } & \multicolumn{2}{|c|}{8 WAPOST } & \multicolumn{2}{|c|}{ Yield } \\
\hline & & & & & & & & & & \\
\hline Pyroxasulfone & 89 & PRE & 85 & $\mathrm{~b}$ & 83 & b & 80 & $\mathrm{~b}$ & 2092 & $\mathrm{~b}$ \\
\hline Pyroxasulfone & 178 & PRE & 88 & $\mathrm{~b}$ & 86 & $\mathrm{~b}$ & 84 & $\mathrm{~b}$ & 2049 & $\mathrm{~b}$ \\
\hline Propoxycarbazone & 29 & PRE & 78 & $c$ & 76 & c & 71 & $c$ & 1942 & $\mathrm{~b}$ \\
\hline Imazamox & 44 & POST & 87 & $\mathrm{~b}$ & 85 & $\mathrm{~b}$ & 80 & $\mathrm{~b}$ & 2003 & $\mathrm{~b}$ \\
\hline Pyroxsulam & 18 & POST & 74 & $c$ & 69 & d & 61 & $\mathrm{~d}$ & 1700 & c \\
\hline Pyroxasulfone $\mathrm{fb}$ imazamox & $89 \mathrm{fb} 44$ & PRE fb POST & 98 & $\mathrm{a}$ & 98 & a & 99 & $\mathrm{a}$ & 2635 & a \\
\hline Propoxycarbazone by imazamox & $29 \mathrm{fb} 44$ & PRE fb POST & 97 & $\mathrm{a}$ & 98 & a & 98 & $\mathrm{a}$ & 2712 & $\mathrm{a}$ \\
\hline Nontreated check & - & - & - & & - & & - & & 884 & $\mathrm{~d}$ \\
\hline
\end{tabular}

${ }^{\mathrm{a}}$ Year-by-treatment interactions for downy brome injury and wheat grain yield were not significant; therefore, data were combined across the two years; ${ }^{\mathrm{b}}$ Abbreviations: PRE, preemergence; POST, postemergence; WAPOST, weeks after POST herbicide application; fb, followed by; g.ai.ha ${ }^{-1}$, gram active ingredient per hectare; ' ${ }^{c}$ Means within a column followed by same letters are not significantly different according to Fisher's protected LSD test at $\mathrm{P} \leq 0.05$.

wheat [28]. However, the POST standalone treatment of pyroxsulam at $18 \mathrm{~g} \cdot \mathrm{ai} \cdot \mathrm{ha}^{-1}$ was the least effective treatment (61\%) for downy brome injury in our study conducted in winter wheat.

Consistent with an excellent downy brome injury, winter wheat yield with pyroxasulfone or propoxycarbazone PRE followed by imazamox POST was higher (averaged $2673 \mathrm{~kg} \cdot \mathrm{ha}^{-1}$ ) than all other treatments. The season-long infestation of downy brome reduced winter wheat yield by an average of $67 \%$ in the non treated check plots compared to the PRE fb POST programs. Winter wheat yield with pyroxasulfone (89 or $178 \mathrm{~g} \cdot a \mathrm{i} \cdot \mathrm{ha}^{-1}$ ) or propoxycarbazone (29 g.ai $\cdot \mathrm{ha}^{-1}$ ) PRE standalone program was comparable to imazamox POST standalone program, averaging $2021 \mathrm{~kg} \cdot \mathrm{ha}^{-1}$, but was higher than the yield obtained from pyroxsulam POST standalone program.

\subsection{Pyroxasulfone Preplant}

Pyroxasulfone applied PP did not cause any visual injury to winter wheat, irres-

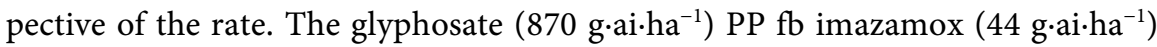
POST program caused $93 \%$ injury to downy brome at 8 WAPOST. There was no additional advantage of tank mixing pyroxasulfone $\left(89 \mathrm{~g} \cdot \mathrm{ai} \cdot \mathrm{ha}^{-1}\right)$ or propoxycarbazone (29 g.ai ha ${ }^{-1}$ ) with glyphosate PP when fb imazamox POST for downy brome injury (Table 4). Similarly, there was no additional benefit of adding pyroxasulfone (89 g.ai ha $\left.{ }^{-1}\right)$ to glyphosate PP when $\mathrm{fb}$ pyroxsulam (18 g.ai $\left.\cdot \mathrm{ha}^{-1}\right)$, with injury averaging $85 \%$. However, the end-season downy brome injury did not exceed $15 \%$ with glyphosate PP standalone treatment, which was most likely because of downy brome cohorts that emerged after the burndown glyphosate application in winter wheat. Similarly, a poor downy brome injury (30\%) was 
Table 4. Comparison of pyroxasulfone with standard glyphosate-based burn down (preplant) programs for downy brome injury and grain yield in imidazolinone-tolerant (IMI-tolerant) winter wheat near Huntley, MT in 2013 and 2014. ${ }^{\mathrm{a}, \mathrm{b}, \mathrm{c}}$

\begin{tabular}{|c|c|c|c|c|c|c|c|c|c|c|}
\hline \multicolumn{11}{|c|}{ Downy brome injury } \\
\hline \multirow[t]{2}{*}{ Herbicide(s) } & \multirow[t]{2}{*}{ Rate } & \multicolumn{2}{|c|}{ Timing } & \multicolumn{2}{|c|}{21 WAPRE } & \multicolumn{2}{|c|}{4 WAPOST } & \multicolumn{2}{|c|}{8 WAPOST } & Yield \\
\hline & & \multicolumn{2}{|c|}{$\left(\mathrm{g} \cdot \mathrm{ai} \cdot \mathrm{ha}^{-1}\right)$} & & & \multicolumn{2}{|c|}{$\%$} & & & $\mathrm{~kg} \cdot \mathrm{ha}^{-1}$ \\
\hline Glyphosate & 870 & PP & 39 & $\mathrm{e}$ & 26 & $\mathrm{f}$ & 15 & e & 1270 & $\mathrm{~d}$ \\
\hline Glyphosate + pyroxasulfone & $870+89$ & PP & 78 & c & 69 & $\mathrm{e}$ & 65 & $\mathrm{~d}$ & 1467 & c \\
\hline Glyphosate + pyroxasulfone & $870+178$ & PP & 88 & $\mathrm{ab}$ & 81 & $\mathrm{~d}$ & 74 & c & 1597 & $\mathrm{bc}$ \\
\hline Glyphosate + propoxycarbazone & $870+29$ & $\mathrm{PP}$ & 89 & $\mathrm{ab}$ & 78 & $\mathrm{~d}$ & 73 & c & 1501 & c \\
\hline $\begin{array}{l}\text { Glyphosate + pyroxasulfone + } \\
\text { saflufenacil }\end{array}$ & $870+89+25$ & PP & 87 & $\mathrm{ab}$ & 83 & $\mathrm{~d}$ & 77 & c & 1568 & $\mathrm{bc}$ \\
\hline $\begin{array}{l}\text { Glyphosate + pyroxasulfone } \\
\text { fbpyroxsulam }\end{array}$ & $870+89 \mathrm{fb} 18$ & PP fb POST & 82 & $\mathrm{bc}$ & 90 & c & 85 & $\mathrm{~b}$ & 1683 & $\mathrm{ab}$ \\
\hline $\begin{array}{l}\text { Glyphosate + propoxycarbazone } \\
\text { fbimazamox }\end{array}$ & $870+29 \mathrm{fb} 44$ & PP fb POST & 91 & $\mathrm{a}$ & 99 & $\mathrm{a}$ & 94 & $\mathrm{a}$ & 1734 & $\mathrm{a}$ \\
\hline $\begin{array}{l}\text { Glyphosate + pyroxasulfone } \\
\text { fbimazamox }\end{array}$ & $870+89 \mathrm{fb} 44$ & PP fb POST & 80 & c & 95 & $a b c$ & 94 & $\mathrm{a}$ & 1766 & $\mathrm{a}$ \\
\hline Glyphosate fb imazamox & $870 \mathrm{fb} 44$ & PP fb POST & 39 & e & 97 & $\mathrm{ab}$ & 93 & $\mathrm{a}$ & 1769 & a \\
\hline Glyphosate fb pyroxsulam & $870 \mathrm{fb} 18$ & PP fb POST & 42 & e & 91 & $\mathrm{bc}$ & 85 & $\mathrm{~b}$ & 1671 & $\mathrm{ab}$ \\
\hline Nontreated check & - & - & - & & - & & - & & 1200 & de \\
\hline
\end{tabular}

${ }^{a}$ Year-by-treatment interactions for downy brome injury and wheat grain yield were not significant; therefore, data were combined across the two years. ${ }^{b}$ Abbreviations: PP, preplant; POST, postemergence; WAPP, weeks after PP application; WAPOST, weeks after POST application; fb, followed by; g.ai.ha ${ }^{-1}$, gram active ingredient per hectare. 'Means within a column followed by same letters are not significantly different according to Fisher's protected LSD test at $\mathrm{P} \leq 0.05$.

reported when glyphosate was applied alone PP in spring wheat [28]. In our study, tank mixing pyroxasulfone $\left(178 \mathrm{~g} \cdot a \mathrm{a} \cdot \mathrm{ha}^{-1}\right)$ with or without saflufenacil (25 g.ai ha $\left.{ }^{-1}\right)$ or propoxycarbazone $\left(29 \mathrm{~g} \cdot \mathrm{ai} \cdot \mathrm{ha}^{-1}\right)$ with glyphosate applied PP (standalone program), improved the end-season downy brome injury (averaged 73\% injury) in winter wheat, indicating the excellent residual activity of those soil-applied herbicides on downy brome.

Wheat grain yields ranged from 1671 to $1769 \mathrm{~kg} \cdot \mathrm{ha}^{-1}$ when glyphosate with or without pyroxasulfone $\left(89 \mathrm{~g} \cdot \mathrm{ai} \cdot \mathrm{ha}^{-1}\right)$ or propoxycarbazone $\left(29 \mathrm{~g} \cdot \mathrm{ai} \cdot \mathrm{ha}^{-1}\right)$ PP was followed by imazamox or pyroxsulam POST (Table 4). In contrast to these glyphosate-based PP fb POST programs, grain yield with a glyphosate-based PP standalone program comprising of pyroxasulfone ( 89 or $178 \mathrm{~g} \cdot \mathrm{ai} \cdot \mathrm{ha} \mathrm{a}^{-1}$ ), propoxycarbazone $\left(29 \mathrm{~g} \cdot \mathrm{ai} \cdot \mathrm{ha}^{-1}\right)$, or pyroxasulfone + saflufenacil $\left(25 \mathrm{~g} \cdot \mathrm{a} \cdot \mathrm{ha} \mathrm{h}^{-1}\right)$ averaged $1533 \mathrm{~kg} \cdot \mathrm{ha}^{-1}$. This indicates that a follow up POST herbicide program was needed to prevent wheat yield reductions from downy brome interference, irrespective of the addition of pyroxasulfone or propoxycarbazone with glyphosate applied PP. However, a poor downy brome injury in the absence of pyroxasulfone or propoxycarbazone in the glyphosate PP standalone program resulted in the lowest yield $\left(1270 \mathrm{~kg} \cdot \mathrm{ha}^{-1}\right)$, which did not differ from the nontreated check plots. 


\subsection{Pyroxasulfone Rate, Application Timing and Formulation}

There was no visible crop injury observed with any of the pyroxasulfone formulations, rates, and application timings tested. Only the main effects of application timing and formulation were significant for downy brome injury. Averaged across pyroxasulfone formulations and application rates, downy brome injury was higher with the PRE compared to the DPRE application timing at both the evaluation dates (Table 5). For instance, at 24 and 32 WAPRE, the PRE application of pyroxasulfone provided 84 and $79 \%$ injury to downy brome, respectively, compared with the DPRE treatment with $74 \%$ and $70 \%$ injury, respectively (Table 5). Although downy brome injury did not differ between WDG and SC formulations at 24 WAPRE, the WDG formulation performed slightly better ( $78 \%$ vs $71 \%$ ) than the SC formulation for end-season (32 WAPRE) downy brome injury. There were no significant effects of pyroxasulfone formulation, rate, application timing, and their interactions on winter wheat grain yield (data not shown).

It is worth emphasizing that the recent evolution of downy brome biotypes with $>100$-fold level of resistance to imazamox and cross-resistance to SCT and TP families of ALS inhibitor soriginating in IMI-tolerant (Clearfield ${ }^{\circledR}$ ) winter wheat system in Montana, is a concern for wheat producers [17]. Therefore, the use of pyroxasulfone as an alternative, effective site-of-action herbicide for downy brome management may aid in reducing the selection pressure for resistance development from repeated applications (fall and spring) of ALS-inhibitors in winter wheat. Based on the results from this research, pyroxasulfone when applied PP or PRE in the fall had extended residual activity on downy brome; however, a follow up POST application of pyroxsulam or imazamox (in IMI-tolerant wheat) in the spring was needed to achieve a season-long downy brome management

Table 5. Effect of pyroxasulfone application timing and formulation on downy brome injury in imidazolinone-tolerant (IMI-tolerant) winter wheat near Huntley, MT in 2015 and $2016 .^{\mathrm{a}, \mathrm{b}, \mathrm{c}}$

\begin{tabular}{|c|c|c|}
\hline & \multicolumn{2}{|c|}{ Downy brome injury } \\
\hline & 24 WAPRE & 32 WAPRE \\
\hline Application timing & \multicolumn{2}{|c|}{$\%$} \\
\hline PRE & $84 \mathrm{a}$ & $79 \mathrm{a}$ \\
\hline DPRE & $74 \mathrm{~b}$ & $70 \mathrm{~b}$ \\
\hline \multicolumn{3}{|l|}{ Formulation } \\
\hline WDG & $82 \mathrm{a}$ & $78 \mathrm{a}$ \\
\hline SC & $77 \mathrm{a}$ & $71 b$ \\
\hline \multicolumn{3}{|c|}{$\begin{array}{l}\text { aThe year-by-treatment interaction for downy brome injury was not significant; therefore, data were com- } \\
\text { bined across the two years. }{ }^{b} \text { Abbreviations: WDG, water-dispersible granules; SC, suspension concentrate } \\
\text { PRE, preemergence; DPRE, delayed preemergence (when } 80 \% \text { of germinated wheat seeds had a shoot at } \\
\text { least } 1.2 \mathrm{~cm} \text { long until wheat spiking); WAPRE, weeks after PRE herbicide application. 'Means within a } \\
\text { column followed by same letters are not significantly different according to Fisher's protected LSD test at } \mathrm{P} \\
\leq 0.05 \text {. }\end{array}$} \\
\hline
\end{tabular}


in winter wheat. This PRE/PP fb POST program can potentially prevent downy brome seed additions to the soil seed bank (Jha, personal observation) in winter wheat, which is an important consideration for herbicide resistance management. Pyroxasulfone would potentially be a good fit in the current weed control programs in cereal-based cropping systems of the NGP where pulse crops (dry pea, chickpea, and lentil) have increasingly become common in rotation with winter wheat. Although only wild oat (Avena fatua L.) with resistance to pyroxasulfone has been documented so far (Heap 2017), there is a potential risk of evolving resistance to pyroxasulfone in other weed species including downy brome, if not used proactively. Therefore, appropriate product stewardship and diverse weed control tactics should be implemented to maintain the long-term utility of pyroxasulfone for downy brome injury in winter wheat.

\section{Conclusion}

Results from this study highlight that pyroxasulfone applied PP or PRE at use rates of 89 or $178 \mathrm{~g} \cdot a \mathrm{i} \cdot \mathrm{ha}^{-1}$ in the fall followed by a POST treatment of imazamox at $44 \mathrm{~g} \cdot \mathrm{ai} \cdot \mathrm{ha}^{-1}$ in the spring can be safely used in Clearfield winter wheat to effectively manage downy brome. The WDG formulation of pyroxasulfone may be slightly superior to the SC formulation, and the PRE timing can potentially provide better early-season downy brome management than the DPRE application timing. Utilizing this relatively new PRE herbicide would add diversity (multiple sites of action) to downy brome management programs in winter wheat.

\section{Acknowledgements}

We thank Nicholas Reichard, Shane Leland, and Charlemagne A. Lim for their assistance in conducting the field research. We also thank BASF for providing funds to conduct this research.

\section{References}

[1] USDA-NASS (United States Department of Agriculture National Agricultural Statistics Service) (2017) Montana Agricultural Facts 2016. USDA-NASS, Helena, MT. https://www.nass.usda.gov/Statistics_by_State/Montana/Publications/Special_Intere st_Reports/agfacts.pdf

[2] Reddy, S.S., Stahlman, P.W. and Geier, P.W. (2013) Downy Brome (Bromustectorum L.) and Broadleaf Weed Control in Winter Wheat with Acetolactate Synthase-Inhibiting Herbicides. Agronomy, 3, 340-348. https://doi.org/10.3390/agronomy3020340

[3] Derksen, D.A., Anderson, R.L., Blackshaw, R.E. and Maxwell, B. (2002) Weed Dynamics and Management Strategies for Cropping Systems in the Northern Great Plains. Agronomy Journal, 94, 174-185. https://doi.org/10.2134/agronj2002.0174

[4] Bell, A.R. and Nalewaja, J.D. (1968) Competition of Wild Oat in Wheat and Barley. Weed Science, 16, 505-508.

[5] Dahl, G.K., Dexter, A.G. and Nalewaja, J.D. (1982) Kochia Competition and Control in Wheat. Proceedings of the North Central Weed Control Conference, Indianapolis, 7-9 December 1982, 15-16. 
[6] Morrow, L.A. and Stahlman, P.W. (1984) The History and Distribution of Downy Brome (Bromustectorum) in North America. Weed Science, 32, 2-6.

[7] Hitchcock, A.S. (1950) Manual of the Grasses of the United States. 2nd Edition, United States Government Printing Office, Washington DC, 1051.

[8] Rice, P.M. (2005) Downy Brome. In: Duncan, C.L. and Clark, J.K., Eds., Invasive Plants of Range and Wildlands and Their Environmental, Economic, and Societal Impacts, Weed Science Society of America, Lawrence, KS, 147-170.

[9] Rydrych, D.J. (1974) Competition between Winter Wheat and Downy Brome. Weed Science, 22, 211-214.

[10] Wicks, G.A., Burnside, O.C. and Fenster, C.R. (1971) Influence of Soil Type and Depth of Planting on Downy Brome Seeds. Weed Science, 19, 82-86.

[11] Thill, D.C., Beck, K.G. and Callihan, R.H. (1984) The Biology of Downy Brome (Bromus tectorum). Weed Science, 32, 7-12.

[12] Sheley, R.L. and Petroff, J.K., Eds. (1999) Biology and Management of Noxious Rangeland Weeds. Oregon State University Press, Corvallis, 428.

[13] Blackshaw, R.E. (1993) Downy Brome (Bromus tectorum) Density and Relative Time of Emergence Affects Interference in Winter Wheat (Triticum aestivum). Weed Science, 41, 551-556.

[14] Rydrych, D.J. and Muzik, T.J. (1968) Downy Brome Competition and Control in Dryland Wheat. Agronomy Journal, 60, 279-280. https://doi.org/10.2134/agronj1968.00021962006000030010x

[15] Stahlman, P.W. and Miller, S.D. (1990) Downy Brome (Bromus tectorum) Interference and Economic Thresholds in Winter Wheat (Triticum aestivum). Weed Science, 38, 221-228.

[16] Heap, I.M. (2017) The International Survey of Herbicide Resistant Weeds. http://www.weedscience.org

[17] Kumar, V. and Jha, P. (2017) First Report of Ser $_{653}$ Asn Mutation Endowing High-Level Resistance to Imazamox in Downy Brome (Bromus tectorum L.). Pest Management Science. https://doi.org/10.1002/ps.4673

[18] Park, K.W., Fandrich, L. and Mallory-Smith, C.A. (2004) Absorption, Translocation, and Metabolism of Propoxycarbazone-Sodium in ALS-Inhibitor Resistant Bromus tectorum Biotypes. Pesticide Biochemistry and Physiology, 79, 18-24. https://doi.org/10.1016/j.pestbp.2003.11.002

[19] Park, K.W. and Mallory-Smith, C.A. (2004) Physiological and Molecular Basis for ALS Inhibitor Resistance in Bromus tectorum Biotypes. Weed Research, 44, 71-77. https://doi.org/10.1111/j.1365-3180.2003.00374.x

[20] Tanetani, Y., Kaku, K., Kawai, K., Fujioka, T. and Shimizu, T. (2009) Action Mechanism of a Novel Herbicide, Pyroxasulfone. Pesticide Biochemistry and Physiology, 95, 47-55. https://doi.org/10.1016/j.pestbp.2009.06.003

[21] Hulting, A.G., Dauer, J.T., Hinds-Cook, B., Curtis, D., Koepke-Hill, R.M. and Mallory-Smith, C. (2012) Management of Italian Ryegrass (Lolium perenne ssp. multiflorum) in Western Oregon with Preemergence Applications of Pyroxasulfone in Winter Wheat. Weed Technology, 26, 230-235. https://doi.org/10.1614/WT-D-11-00059.1

[22] Jha, P., Kumar, V., Garcia, J. and Reichard, N. (2015) Tank Mixing Pendimethalin with Pyroxasulfone and Chloroacetamide Herbicides Enhances In-Season Residual Weed Control in Corn. Weed Technology, 29, 198-206.

https://doi.org/10.1614/WT-D-14-00095.1 
[23] Tidemann, B.D., Hall, L.M., Johnson, E.N., Beckie, H.J., Sapsford, K.L. and Raatz, L.L. (2014) Efficacy of Fall- and Spring-Applied Pyroxasulfone for Herbicide-Resistant Weeds in Field Pea. Weed Technology, 28, 351-360. https://doi.org/10.1614/WT-D-13-00140.1

[24] Boutsalis, P., Gill, G.S. and Preston, C. (2014) Control of Rigid Ryegrass in Australian Wheat Production with Pyroxasulfone. Weed Technology, 28, 332-339. https://doi.org/10.1614/WT-D-13-00094.1

[25] Westra, E.P., Shaner, D.L., Westra, P.H. and Chapman, P.L. (2014) Dissipation and Leaching of Pyroxasulfone and S-Metolachlor. Weed Technology, 28, 72-81. https://doi.org/10.1614/WT-D-13-00047.1

[26] Jacobsen, J., Jackson, G. and Jones, C. (2005) Fertilizer Guidelines for Montana Crops. Montana State University Extension Service Publication, Montana, EB 161.

[27] Walsh, M.J., Fowler, T.M., Crowe, B., Ambe, T. and Powles, S.B. (2011) The Potential for Pyroxasulfone to Selectively Control Resistant and Susceptible Rigid Ryegrass (Lolium rigidum) Biotypes in Australian Grain Crop Production Systems. Weed Technology, 25, 30-37. https://doi.org/10.1614/WT-D-10-00091.1

[28] Ostlie, M.H. and Howatt, K.A. (2013) Downy Brome (Bromustec torum) Competition and Control in No-Till Spring Wheat. Weed Technology, 27, 502-508. https://doi.org/10.1614/WT-D-11-00033.1

\section{Submit or recommend next manuscript to SCIRP and we will provide best service for you:}

Accepting pre-submission inquiries through Email, Facebook, LinkedIn, Twitter, etc. A wide selection of journals (inclusive of 9 subjects, more than 200 journals)

Providing 24-hour high-quality service

User-friendly online submission system

Fair and swift peer-review system

Efficient typesetting and proofreading procedure

Display of the result of downloads and visits, as well as the number of cited articles

Maximum dissemination of your research work

Submit your manuscript at: http://papersubmission.scirp.org/

Or contact ajps@scirp.org 